\title{
EFFECTIVENESS OF "SM" TOOL TO REDUCE DETERGENT LEVELS IN LAUNDRY WASTEWATER
}

\author{
Tri Marthy Mulyasari
}

\author{
Department of Environmental Health \\ Health Polytechnic of the Ministry of Health, Semarang, Indonesia
}

Email Correspondence: tmmulyasari@poltekkes-smg.ac.id

\begin{abstract}
Introduction: The use of detergent every year is increasing in line with the population growth rate in Indonesia. The impact of excessive use of detergent will result in pollution and damage to ecosystems and aquatic biota. The nature of detergents is to damage microorganisms. The dominant laundry waste comes from softeners and detergents. The research aimed to analyze the effectiveness of the "SM" tool to reduce detergent levels in laundry wastewater. Methods: This type of research was pre-experimental with a one-shot case study design. The independent variable was a tool to recycle laundry liquid waste into clean water "SM." The dependent variable was the detergent level (MBAS). The sample came from the laundry in the Kecamatan Baturraden area. Replication was carried out six times. Analyzing differences in detergent levels before and after being treated with the "SM" tool. The analysis used a paired T test. Result and discussion: The experimental results showed the "SM" tool could treat 960 liters of wastewater/day. The physical quality of the water after being treated using the "SM" tool, the water was colorless or clear, but it still smelled slightly fragrantly. The average level of detergent level checks before processing was $2.52 \mathrm{mg} / \mathrm{L}$ and after processing was $0.01 \mathrm{mg} / \mathrm{L}$. The effective detergent parameter (MBAS) decreased by $99.51 \%$, categorized as quite effective. The analysis using the paired $\mathrm{T}$ Test showed the $\mathrm{p}$ value of 0.239 with the lower and upper values being at one pole, meaning there was a significant difference between detergent levels before and after being processed utilizing the "SM" tool. Conclusion: Detergent levels (MBAS) after processing met the chemical quality requirements of clean water in accordance with Regulation of the Minister of Health Number 32 of 2017 concerning Environmental Health Quality Standards and Water Health Requirements for Sanitation Hygiene, Solus Per Aqua and Public Bathing Needs.
\end{abstract}

Keywords: "SM" tool, Detergent Level, Recycling, Wastewater, Laundry

\section{Introduction}

One of the wastes that pollute water bodies is waste from the clothes washing industry or known as laundry. This is because the waste from laundry contains detergents which contain several potential hazards, including the formation of a film in the water which will cause a decrease in the transfer rate into the water, serious health problems for humans, and the combination of polyphosphates and surfactants in detergents can increase the phosphate content in the water (1).

Laundry is a domestic business that produces detergent waste. Excessive use of detergents will pollute and disrupt the biota ecosystem in the water, and dominant laundry waste comes from softeners and detergents. One of the properties of detergents is to destroy microorganisms. The laundry waste that is directly disposed of into the environment or water bodies without prior treatment will cause water bodies and the environment to be polluted by chemicals (2). Laundry wastewater treatment is needed so that laundry waste does not possess the potential to pollute the environment (3).

Laundry waste treatment can be done by flocculating coagulation using alum coagulant and adsorption with zeolite (4). Silica sand can be used as a filter for liquid waste treatment (5). Activated carbon can also be employed as an adsorbent in laundry waste treatment (6). So that the design of the laundry waste processing tool can be prepared by combining silica sand, activated carbon, and zeolite to decompose chemicals in the wastewater.The purpose of this study was to analyze the effectiveness of the "SM" tool to reduce the detergent levels of laundry wastewater.

\section{Methods}

This research was a type of pre-experiment with a one-shot case study design. A laundry liquid waste sample with a volume of 40 liters per replication was utilized in this research. Replication 
was determined by calculating the replication formula to obtain the results of the calculation six times. The independent variable of this research was a tool to recycle laundry liquid waste into clean water "SM." The correlated variable was the detergent level in laundry wastewater.

The "SM" tool consisted of six tubs. The principle of the "SM" tool was to combine physical and chemical processing to reduce detergent levels in laundry wastewater. The use of the "SM" tool was to enter the wastewater into a 60-liter storage tank using a pump. After the water had entered the second tub, we added 30 grams of coagulant and did a quick stirring for 1 minute then stirred slowly for 15 minutes, waited for the flock to settle for 30 minutes. Then we opened the faucet and connect it to the second and third tanks so that the coagulated waste entered the filter tub. The filtration process went through three tubs, each of which was filled with silica sand, activated carbon, and zeolite media with a thickness of each filter media of $50 \mathrm{~cm}$. Water that has passed through the filtration tub would enter the outlet tub to be collected. The treated water could be reused for washing purposes.

The determination of the coagulant alum dosage was based on the jar test results. The principle of the jar test was fast stirring $150 \mathrm{rpm}$ for one minute, slow stirring for 15 minutes then the sedimentation process for 30 minutes. The alum dose specified in the jar test was $0.5 ; 0.6 ; 0.7 ; 0.8 ; 0.9$ gram/liter. The effective coagulant dose was 0.5 gram/lt with a $\mathrm{pH}$ of four and a TDS of $88 \mathrm{ppm}$

\section{Result and Discussion}

a. Detergent Level Check Results Before and After Processing Using "SM" Tool

The results of checking detergent levels before and after being processed using the "SM" tool can be seen in table 1.

Table 1. Analysis of laundry wastewater detergent levels before and after processing employing the "SM" tool.

\begin{tabular}{lll}
\hline \multirow{2}{*}{ Replication } & \multicolumn{2}{l}{ Detergent Levels (mg/l) } \\
\cline { 2 - 3 } & Pre & Post \\
\hline 1 & 2.1 & 0.011 \\
2 & 5.42 & 0.015 \\
3 & 1.6 & 0.011 \\
4 & 1.9 & 0.012 \\
5 & 1.7 & 0.006 \\
6 & 2.4 & 0.011 \\
\hline Average & 2.52 & 0.01 \\
\hline
\end{tabular}

Source: Primary Data, 2020
Detergen Levels (MBAS) of Laundry

Wastewater Before and After Being Treatet Using "SM"Tool

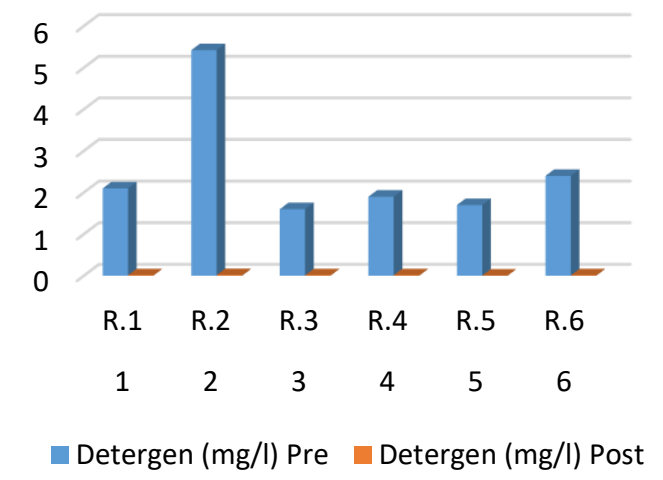

Figure 1. Detergent Levels (MBAS) of Laundry Wastewater Before and After Being Treated Using "SM" Tool

The average detergent levels (MBAS) before being processed using the "SM" tool was 2.52 $\mathrm{mg} /$ liter and after being processed was $0.01 \mathrm{mg} / \mathrm{liter}$.

Wastewater is the residue from a business and/or activity in the form of liquid which, if discharged into the environment, can reduce environmental quality. Wastewater quality standards are the limits or levels of pollutant elements and/or the number of pollutant elements borne in the wastewater to be disposed of or released into the water source of a business and/or activity.

The Regulation of Central Java Province Number 5 of 2012 concerning Wastewater Quality Standards (7) categorizes the quality standards of laundry waste into the quality standards of the soap and detergent industry. One of the parameters is MBAS. The maximum level of the MBAS parameter has also been determined, namely MBAS $3 \mathrm{mg} / \mathrm{L}$.

The results of the study were carried out by examining the MBAS parameters. Before being processed utilizing the "SM" tool, it could be categorized that the sample still exceeded the maximum specified level, which if it is directly disposed of into the environment could cause environmental pollution.

The results of the examination of detergent levels processed employing the "SM" tool were below the maximum permissible levels in laundry wastewater and met the clean water requirements for sanitation hygiene activities based on the requirements in Regulation of the Minister of Health Number 32 of 2017 concerning Environmental Health Quality Standards and Water Health Requirements for Hygiene Purposes Sanitation, Solus Per Aqua and Public Baths (8). 
b. The Effectiveness of the "SM" Tool in Reducing Detergent Levels in Laundry Wastewater

The effectiveness of the tool in reducing detergent levels in laundry wastewater can be seen in table 2 .

Table 2. The effectiveness of the "SM" tool in reducing detergent levels in laundry wastewater.

Replication Effectiveness (\%)

\begin{tabular}{cc}
\hline I & 99.48 \\
II & 99.72 \\
III & 99.31 \\
IV & 99.37 \\
V & 99.65 \\
VI & 99.54 \\
\hline Average & 99.51
\end{tabular}

Source: Primary Data, 2020

\section{Effectiveness of Detergent Reduction (\%)}

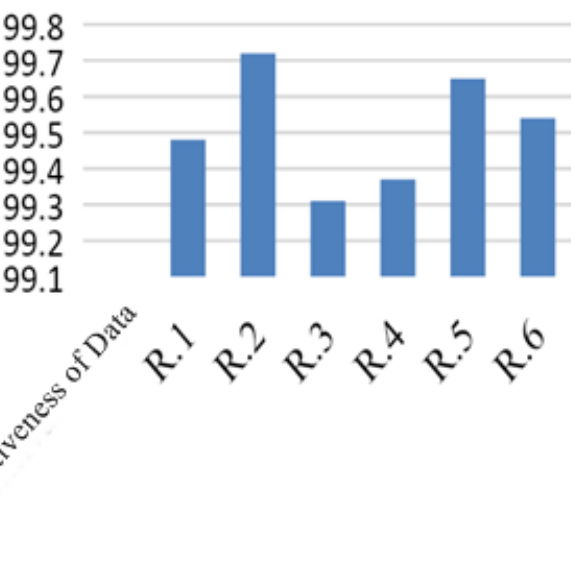

Figure 2. The effectiveness of the "SM" tool in reducing the detergent level of laundry wastewater

The "SM" tool was effective in reducing MBAS or detergent levels by $99.51 \%$. Effectiveness is the match between the output and the goals set. Effectiveness must be assessed based on a workable goal, not on the concept of a maximum goal.

Table 3. Standard Measures of Effectiveness.

\begin{tabular}{ll}
\hline Effectiveness & Achievement \\
Ratio & Level \\
\hline$<40$ & Very \\
$40-59.99$ & ineffective \\
$60-79.99$ & Not effective \\
$>80$ & Quite effective \\
\hline
\end{tabular}

Source: Journal of Measurement of the Effectiveness and Efficiency of School of Informatics Management and Computer Engineering (STIKOM) Bali Eresearch System by Ni Luh Ayu Kartika, et al. (9)

The results of using the "SM" tool to treat laundry water were effective in reducing the main parameters of the laundry waste quality standard. The reduction in detergent levels (MBAS) of $99.51 \%$ was categorized as a very effective one.

In line with the results of research conducted by (10) where laundry waste treatment using activated carbon and zeolite filtration as well as alum coagulants effectively reduced detergent levels (MBAS) by $99.7 \%$.

c. Analysis of Differences in Detergent Levels Before and After Being Processed Using the "SM" Tool

Analysis of differences in detergent levels before and after being processed using the "SM" tool used the paired $\mathrm{T}$ test. This statistical test used bootstrap 2000 times can be seen in table 4 .

Table 4. The Results of the Analysis of Differences in Detergent Levels with the Paired T Test

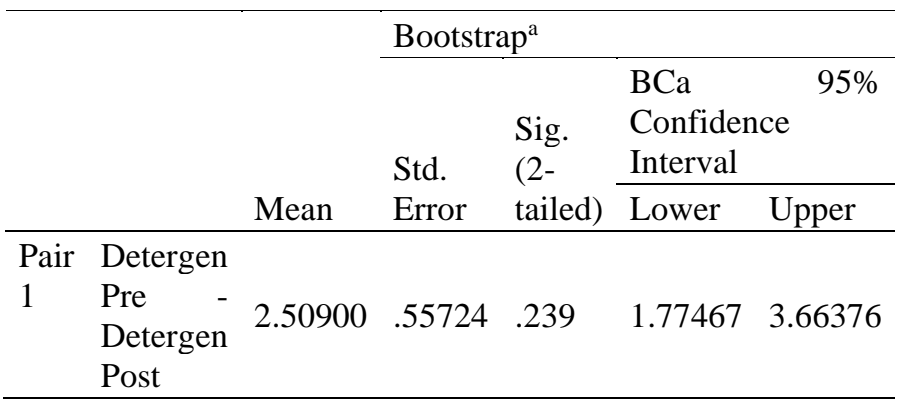

Source: Primary Data 2020

The results of the analysis of detergent levels with a $\mathrm{p}$ value of 0.239 (\&gt; 0.05) with lower and upper values at the same pole, means there was a significant difference in detergent before and after being processed.

In line with research (10), analyzing the efficiency of laundry waste processing equipment to reduce detergent levels in Desa Dukuhwaluh, Kecamatan Kembaran in 2016 using the independent $t$ test showed that there were differences in detergent levels between discharges. The results of the study concluded there were differences in detergent levels after processing with the laundry waste processing tool. There was no significant difference in detergent levels after processing between discharges according to statistics. 


\section{Conclusion}

The "SM" tool consists of six tanks, including a wastewater reservoir, a coagulationflocculation tub, a silica sand filter, an activated carbon filter, a zeolite filter, and an outlet tub. The volume of laundry wastewater that could be treated using the "SM" tool was 960 liters/day. The mean levels of detergent before and after being processed were $2.52 \mathrm{mg} / \mathrm{L}$ and $0.01 \mathrm{mg} / \mathrm{L}$, respectively, which were below the maximum permissible levels. The effectiveness of the "SM" tool in reducing detergent levels by $99.51 \%$ was categorized as a very effective one. There was a significant difference in detergent levels before and after treatment with a $\mathrm{p}$ value of 0.239 , lower and upper values at the same pole. Detergent levels (MBAS) after being processed met the chemical quality requirements of clean water in accordance with Regulation of the Minister of Health

\section{References}

1. Utomo WP, Nugraheni ZV, Rosyidah A, Shafwah OM, Naashihah LK, Nurfitria N, et al. Penurunan Kadar Surfaktan Anionik dan Fosfat dalam Air Limbah Laundry di Kawasan Keputih, Surabaya menggunakan Karbon Aktif. Akta Kim Indones. 2018;3(1):127.

2. Gemala M, Oktarizal H. Rancang Bangun Alat Penyaringan Air Limbah Laundry. Chempublish J. 2019;4(1):38-43.

3. Majid M, Amir R, Umar R, Hengky HK Efektivitas Penggunaan Karbon Aktif Pada Penurunan Kadar Fosfat Limbah Cair Usaha Laundry Di Kota Parepare Sulawesi Selatan. Pros Semin Nas IKAKESMADA "Peran Tenaga Kesehat dalam Pelaks SDGs.” 2017;8591.

4. Sisyanreswari H, Oktian W, Rezagama A. Penurunan TSS, COD, dan Fosfat Pada Limbah Laundry Menggunakan Koagulan Tawas dan Media Zeolit. J Tek Lingkung UNDIP [Internet]. 2016;5(2):103-14. Available from: eprints.undip.ac.id/49597/

5. Setiawati DA, Putra GMD, Khalil FI, Zulfikar W, Hirjani H. Aplikasi Kombinasi Filter Bertingkat Untuk Pengolahan Limbah Cair
Number 32 of 2017 concerning Environmental Health Quality Standards and Water Health Requirements for Sanitation Hygiene, Solus Per Aqua and Public Baths (8).

It is necessary to make an automatic fast and slow mixer. It needs increasing the sedimentation time so that the flock formed can settle completely so that the TDS after processing does not increase. It is necessary to add lime to the filtration process to increase the $\mathrm{pH}$ of the water after treatment.

\section{Acknowledgment}

These acknowledgments are conveyed to:

a. Health Polytechnic of the Ministry of Health, Semarang, which has provided research funding.

b. Families who have provided motivation and enthusiasm for the research activities.

Industri Tempe Di Kelurahan Kekalik Jaya Kota Mataram. Abdi Insa. 2019;6(1):13.

6. Sri Widya Astuti, Mersi Suriani Sinaga. Pengolahan Limbah Laundry Menggunakan Metode Biosand Filter Untuk Mendegradasi Fosfat. J Tek Kim USU. 2015;4(2):53-8.

7. Perda Provinsi Jawa Tengah. Perubahan Peraturan Daerah Provinsi Jawa Tengah Nomor 10 Tahun 2004 Tentang Baku Mutu Air Limbah. 2012;

8. Peraturan Menteri Kesehatan. Standar Baku Mutu Kesehatan Lingkungan dan Persyaratan Kesehatan Air untuk Keperluan Higiene Sanitasi, Kolam Renang, Solus Per Aqua, dan Pemandian Umum. Peratur Menteri Kesehat Republik Indones. 2017;

9. Luh Ayu Kartika Yuniastari S N, Wiyati RK. Pengukuran Tingkat Efektivitas Dan Efisiensi Sistem Eresearch STIKOM Bali. Konf Nas Sist Inform. 2015;9-10.

10. Tsabity MW, IW HR. Efisiensi Alat Pengolah Limbah Laundry Untuk Menurunkan Kadar Deterjen Di Desa Dukuhwaluh Kecamatan Kembaran Tahun 2016. Bul Keslingmas. 2017;36(4):378-85. 